Nicolai Kristensen and Edvard Johansson

New Evidence on Cross-Country Differences in Job Satisfaction Using Anchoring Vignettes

Department of Economics 


\title{
New Evidence on Cross-Country Differences in Job Satisfaction Using Anchoring Vignettes*
}

\author{
Nicolai Kristensen \\ Department of Economics, Aarhus School of Business and CCP \\ nik@asb.dk \\ Edvard Johansson \\ The Research Institute of the Finnish Economy \\ edvard.johansson@etla.fi
}

January, 2006

\begin{abstract}
This paper presents results on cross-country comparison of job satisfaction across seven EU countries taking into account that people in different countries may perceive subjective questions differently. We apply a chopit model approach where the threshold parameters in an ordered probit model are re-scaled through anchoring vignettes. Compared to a traditional ordered probit model, which yields the familiar result that Denmark is ranked in the very top followed by Finland, the country ranking is altered when the chopit model is applied. In this case, the Scandinavian countries are ranked somewhat lower while workers from the Netherlands are found to have the highest level of job satisfaction. These results suggest that cultural differences in the way people perceive subjective questions about satisfaction make simple cross-country comparison misleading.

JEL Classification: C25, I31 Model

Keywords: Job Satisfaction, Cross-Country Comparison, Chopit
\end{abstract}

${ }^{*}$ We thank the members of the EU-funded Epicurus project, and especially Ada FerrerI-Carbonell, Bernard van Praag and Ioannis Theodossiou, for the creation of the "Epicurus database". We also thank Andrew E. Clark, Tor Eriksson and seminar participants at the Aarhus School of Business for helpful comments. 


\section{Introduction}

Within the economics profession, a series of studies on subjective well-being, life satisfaction and job satisfaction have proliferated in recent years, (see Frey and Stutzer 2002a, Frey and Stutzer 2002b and van Praag and Ferrer-iCarbonell 2004 for recent, large scale surveys). In some studies, job satisfaction or overall life satisfaction has been regressed, using some kind of ordered logit or probit approach, on a number of variables using cross-country data, and country dummies have then been used to capture country-specific effects.

Interestingly, cross-country studies of happiness with life or satisfaction with work find surprisingly consistent results in the ranking of nations. For instance, Denmark and Ireland are persistently ranked in the very top with respect to well-being (Eurobarometer 2002, Inglehart and Klingemann 2000, Easterlin 2001) and job satisfaction (Clark 2005, Ahn and Garcia 2004, Blanchflower and Oswald 1999, Kaiser 2002). ${ }^{1}$

The validity of these satisfaction studies is important for a number of reasons. First, many private companies periodically evaluate their employees' job satisfaction. This is of great concern to managers who seek to abstain employees from quitting (Clark 2001) and because it is generally believed that satisfied workers are more productive than dissatisfied workers (Pfeffer and Langton 1993, Patterson et al. 2004).

Second, satisfaction studies often attract a lot of attention from the news media, which in itself may increase the probability that politicians will react upon the results of these studies.

Third, the demographic evolution towards ageing populations in OECD countries puts strain on public finances since, ceteris paribus, a lower share of the population will be working and pay taxes to finance government spending while, possibly, the pressure on public health care and pension systems may increase. For this reason there is a clear objective formulated in the socalled Barcelona and Stockholm targets of the European Union to increase the age in which people exit the labor market. In recent years, the European Commission has consequently devoted a lot of attention to the quality of jobs (EU 2001, 2002, 2003), and indicators of quality have been chosen based on their ability to predict self-reported job satisfaction (EU 2002, p. 81).

Hence, satisfaction studies, including cross-country studies, are highly important for development of public policies as well as for human resource

\footnotetext{
${ }^{1}$ World Value Survey also finds this. See http://www.worldvaluessurvey.org/statistics/
} index.html. 
management. For instance, if it truly is the case that job satisfaction is higher in Denmark and Ireland than in other countries then one could argue that working life should be arranged in a way that resembles the labour market in these countries.

However, the problem with studies that have been done up to this date is that it is unclear whether the results are due to the fact that it actually is nicer to work in Ireland or Denmark or whether the Irish and the Danes perceive questions of job satisfaction in different ways compared to people in other countries. More generally, one of the inherent problems with using subjective answers to questions on individual well-being is that individuals, at least from different cultures, may perceive these questions in different ways, and that there may therefore by systematic differences across groups of sub-populations. As answers to questions on individual well-being most often are reported on a discrete scale, this means, in a technical sense, that the response category cut points for the different evaluations of self-assessed happiness or job satisfaction will differ between groups.

Layard (2003) and Veenhoven (2000) both discuss the possibility of cultural differences in reporting satisfaction and happiness but note that, to date, "There is no evidence of this..." (Layard 2003, p. 19) (i.e. of cultural differences in reporting happiness), and hence conclude that "For the present it appears that self-reports of overall happiness can be meaningfully compared across nations" (Veenhoven 2000, p. 271).

In this paper, we seek to provide evidence of whether or not there are any cultural differences in reports of satisfaction. Our approach to remedy this potential problem takes as its starting point the correction of response category cut points by the means of anchoring vignettes. This methodology has earlier been applied in other social sciences, e.g. in political science (King et al. 2004) and in medicine (Salomon et al. 2004).

The idea behind this method is that respondents, in addition to stating how satisfied they are with their own life or job, are asked to evaluate, on the same scale, how good or bad a set of hypothetical jobs or life situations are. This information is then used to rescale individuals' real evaluation of their own situation, using a joint, so-called chopit model (compound hierarchical ordinal probit, see Rabe-Hesketh and Skrondal 2002) for the job satisfaction question and the vignettes. Thus, if one particular group, say the Danes, systematically gives higher valuations of hypothetical jobs compared to other nationalities that rank the exact same hypothetical jobs, this would indicate that differences in job satisfaction are due to cultural differences in evaluating such subjective questions and not due to better organization of workplaces or better work environment in Denmark. 
Hence, in this paper we re-examine cross-country differences in job satisfaction using anchoring vignettes. We contribute to the satisfaction literature by examining to which extent cross-country differences in job satisfaction adhere to cultural differences in responding to subjective questions, or if indeed cross-country differences in job satisfaction do reject "true" differences in job satisfaction. This is done using data from a purpose-built questionnaire, applied to seven EU countries, and asking respondents to rank their own job as well as hypothetical jobs. The analysis extends the standard ordered probit model along two dimensions. First, and most importantly, by using vignettes we are able to re-scale respondents' answers in order to make them comparable across countries. Second, the thresholds are allowed to depend on covariates.

Our main finding is that, while the standard ordered probit model applied to our data yields the traditional result that Scandinavian countries are ranked in the top, this ranking is altered when anchoring is applied. In this case the Scandinavian countries are ranked somewhat lower while workers from the Netherlands are found to have the highest level of job satisfaction. These results provide the first evidence of cultural differences in reporting of satisfaction and indicate that simple cross-country comparison may be misleading.

\section{Methodology}

The standard way of analyzing answers to questions about job satisfaction is to apply an ordered probit or logit model. However, this approach does not take into account any individual differences in interpretation of the question about job satisfaction. The method we apply in this paper is based on King et al. (2004), where two important extensions to the ordered probit model are introduced. ${ }^{2}$

First, since self-assessment of job satisfaction potentially is incomparable across countries (or sub-populations), we seek to measure how responses differ across countries and use this measure to correct the self-assessment answers in order to make these comparable. The incomparability is measured by respondents' assessments of hypothetical jobs, which are described in vignettes and assessed on the same scale as the respondents' own current job.

Second, the method allows the threshold parameters in the ordered probit model to differ across respondents and estimate these heterogeneous

\footnotetext{
${ }^{2}$ See also Tandon et al. (2003) and http://gking.harvard.edu/vign/.
} 
thresholds using covariates, cf. Groot and van den Brink (1999).

\subsection{Vignettes}

Vignettes have been used in conjoint analyses in market research and other fields for many years, e.g. Green and Srinivasan (1978). In economics, vignettes have not been widely used although examples do exist, e.g. van Beek et al. (1997). In the present context, a vignette describes the content of a hypothetical job, for example one vignette looks as follows.

\begin{tabular}{|c|c|c|}
\hline Type of contract & $\begin{array}{l}\text { Permanent with a risk of losing the job and then } \\
\text { receive unemployment benefits }\end{array}$ & More \\
\hline Number of work hours & 50 hours per week & More \\
\hline Influence on own work & Nobody but you decide over your work & More \\
\hline Organisation of the work & The job entails work in different teams & More \\
\hline Start/end time & $\begin{array}{l}\text { The employer decides on work hours (not night } \\
\text { shifts) and can change this on a monthly basis }\end{array}$ & More \\
\hline Education and training & The employer will not offer you a specific education & \\
\hline Intensity & $\begin{array}{l}\text { The job is very demanding, which means that you } \\
\text { need to stick to tight deadlines most of the time }\end{array}$ & \\
\hline Pension age & This firm has no early retirement plan & More \\
\hline Akerlof theory & $\begin{array}{l}\text { Same working conditions as in other companies } \\
\text { Loyalty from both sides } \\
\text { No possibilities for shirking }\end{array}$ & More \\
\hline Net wage & $10 \%$ less per hour than your current job & \\
\hline
\end{tabular}

Figure 1 Example of Vignette

Each respondent is presented with five different hypothetical jobs, i.e. five vignettes. For each vignette, the respondent is asked to rate this fictive job on a scale from 0 (worst possible) to 10 (best possible), like respondents also evaluate their own current job on the same scale, cf. section 3 .

The left column of Figure 1 lists the variables considered for the fictive jobs. These are the same for all vignettes. The center column describes the values of the variables in this particular vignette. Contrary to the respondents' own jobs, these hypothetical jobs are the same across all individuals. Hence, the rating from the vignettes can be used to re-scale the ratings of 
individuals' self-assessment of their current jobs. ${ }^{3}$

There are two critical assumptions that need to hold in order for this method to be valid.

Assumption 1 Response Equivalence: Individuals use the response categories for the job satisfaction questions in the same way when they evaluate hypothetical scenarios as they do when they provide self reported assessments of their own current jobs.

Assumption 2 Vignette Equivalence: The domain levels represented in each vignette are understood in the same way by all respondents, irrespective of their country of residence or other sociodemographic variables.

These assumptions are not necessarily innocent. In particular, vignette equivalence implies that, for each vignette, there is an actual (unobserved) level of job satisfaction which everybody agrees to. In other words, all respondents value the specific job contents in the same manner. Differences in institutional settings across countries may be one reason why this assumption might not hold. For instance, "Type of contract" may matter less in the Nordic countries where welfare benefits are very generous while a permanent contract is considered more important, vis-á-vis other job characteristics, in countries with less generous welfare benefits. The assumption about vignette equivalence limits the scope and applicability of the method to countries and cultures that are relatively homogenuous.

However, this difficulty should not be overemphasized. The countries included in this study are not too dissimilar - they all belong to the EU, and they have very similar per capita GDP levels, at least in an international perspective. Furthermore, in earlier research using similar methodology, countries as far apart as China and Mexico have been included successfully in the same study.

\subsection{Model for Self-Assessment of Job Satisfaction}

The latent (unobserved) perceived level of job satisfaction of individual $i$, $J S_{i}^{*}$, is modelled as an ordered probit model

$$
J S_{i}^{*}=X_{i}^{\prime} \beta+\varepsilon_{i}
$$

\footnotetext{
${ }^{3}$ Data were collected through the internet, as described in section 3 . The right column was introduced in order to give respondents an opportunity to gain a more extensive explanation of the description in the center column.
} 
where $X_{i}$ includes covariates, $\beta$ includes parameters and $\varepsilon_{i}$ is an individual residual error term, assumed to be standard normal distributed, $\varepsilon_{i} \sim$ $N(0,1)$.

Respondent $i$ turns the continuous perceived level of satisfaction with his/her job into the reported category, $j s_{i}$, where

$$
j s_{i}=k \text { if } \tau_{i}^{k-1} \leq J S_{i}^{*}<\tau_{i}^{k}
$$

and where $-\infty=\tau_{i}^{0}<\tau_{i}^{1}<\ldots<\tau_{i}^{K}=\infty$, and $K=10$.

The thresholds are allowed to vary over the observations as a function of covariates $Z_{i}$, which may overlap with $X_{i}$.

$$
\begin{aligned}
\tau_{i}^{1} & =\gamma^{1} Z_{i} \\
\tau_{i}^{k} & =\gamma^{k-1}+e^{\gamma^{k^{1}} Z_{i}} \quad, k=2, \ldots, 10 .
\end{aligned}
$$

where $\gamma^{k}$ are parameters.

\subsection{Model for Vignettes}

The assumption of vignette equivalence means that there is a "true" (objective) actual level of job satisfaction underlying each hypothetical job. For vignette $j$, we denote this "true" (unobserved) actual level as $\theta_{j}(j=1, \ldots, 95)$, which is not subscripted by respondent - a direct formalization of vignette equivalence. As not all $N$ respondents have been subjected to the same five vignettes, cf. section 3 , we denote respondents to vignettes by index $l$.

Respondent $l$ perceives $\theta_{j}$ with (normal random) error, so that

$$
V_{l, j}^{*} \sim N\left(\theta_{j}, \sigma^{2}\right)
$$

becomes respondent $l^{\prime} s$ continuous, unobserved perception of the actual level of job satisfaction for vignette $j$.

Respondent $l$ turns the perception of job satisfaction related to the hypothetical job into reported categories in a similar manner as for the selfassessment. The rule here is

$$
v_{l, j}=k \text { if } \tau_{l}^{k-1} \leq V_{l, j}^{*}<\tau_{l}^{k} .
$$

The thresholds are determined by the same $\gamma$ coefficients as in the model for self-assessment of job satisfaction and the same explanatory variables, measured for respondent $l, Z_{l}$. 


$$
\begin{aligned}
\tau_{l}^{1} & =\gamma^{1} Z_{l} \\
\tau_{l}^{k} & =\gamma^{k-1}+e^{\gamma^{k^{\prime}} Z_{l}} \quad, k=2, \ldots, 10 .
\end{aligned}
$$

By applying the same thresholds in the vignette model as in the selfassessment model, we enforce response equivalence. Since the variance in the self-assessment model is normalized to one, we are able to identify the variance of the latent variable in the vignette model, i.e. there is no need to set the variance equal to 1 as in the self-assessment model.

The likelihood function for the entire model consists of a self-assessment part and a vignette part, which are additive. Hence, the joint likelihood expression becomes

$$
L(\beta, \theta, \gamma \mid j s, v)=L_{s}(\beta, \gamma \mid j s) \times L_{v}(\theta, \gamma \mid v)
$$

where $L_{s}(\beta, \gamma \mid j s)$ is the likelihood component for the self-assessment part and $L_{v}(\theta, \gamma \mid v)$ is the likelihood component for the vignette part, see Appendix A for more details. The model outlined in this section is called a compound chopit model (compound hierarchical ordinal probit, see RabeHesketh and Skrondal 2002, King et al. 2004).

\section{Data}

The data applied in the estimations were collected in the autumn of 2004 in $7 \mathrm{EU}$ countries, in which an identical questionnaire was administered through the internet for a total of 5,988 respondents. ${ }^{4}$ The respondents, all aged between 18 and 65 years, were employees only, with a relatively low education (upper secondary education or lower).

The question on overall job satisfaction reads:

All in all, how satisfied or dissatisfied are you with your current occupation on a scale from 0 to 10 ? ( $0=$ Very dissatisfied and $10=$ Very satisfied).

As already mentioned, respondents were presented to vignettes with descriptions of hypothetical jobs (see Figure 1) and requested to rank these

\footnotetext{
${ }^{4}$ The countries are Denmark, France, Greece, the Netherlands, Spain, UK and Finland. In Greece, data were collected through personal interviews. The data were collected as part of an EU project. See http://www.abdn.ac.uk/epicurus/.
} 
imaginary jobs on the same scale as they evaluated their own job, i.e. on a 0-10 scale.

Each respondent answered to one set of five vignettes. However, 19 different sets (each with five different vignettes) were used. Hence, there are about 315 respondents for each set of vignettes and 95 different vignettes in total. In Appendix B, we list all attribute levels used in the vignettes.

In addition, the purpose-built data set also contains standard demographic information as well as detailed information about job characteristics and work environment.

\section{Results}

As noted in the introduction, simple cross-country comparison of job satisfaction almost always identify Danes as the most satisfied workers. The data applied in this study are no exception, cf. Figure 2.

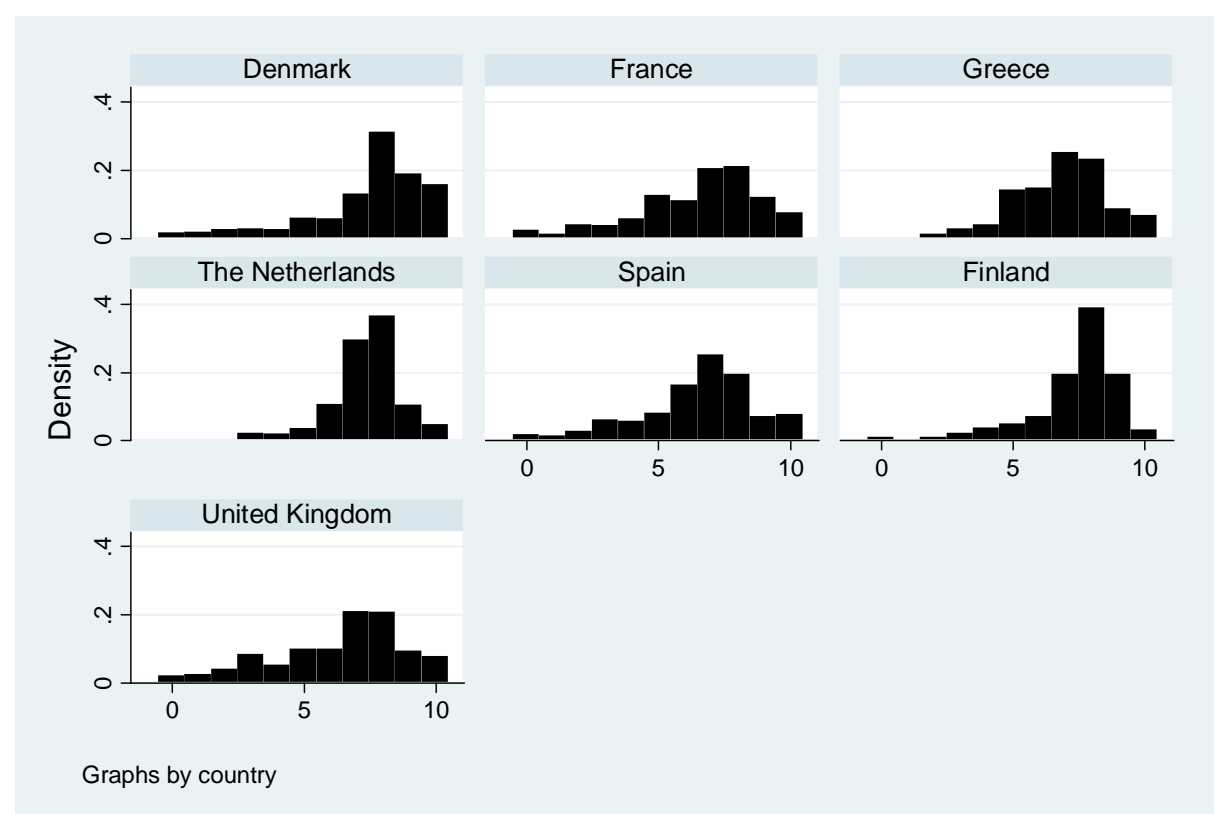

Figure 2 Histograms of self-assessed job satisfaction, by country.

More than 60 percent of Danish workers indicate a level of satisfaction at level 8 or higher, while the corresponding number is less than 38 percent in the UK. The average value is also highest in Denmark (7.5), followed by 
Finland (7.4) and the Netherlands (7.3). Lowest average values are found in the UK (6.4), Spain (6.5) and France (6.6). Greece is found in the mid range with an average value of 6.9 .

\subsection{Regression Results}

In order to facilitate comparisons with earlier research done on this topic, we present results from a standard ordered probit regression as well as results from the chopit model. The chopit model presented in section 2 has been estimated using GLLAMM. ${ }^{5}$ Parameter estimates of country dummies are of primary interest.

Estimation results from the standard ordered probit model confirm results from previous studies (Clark 2005, Ahn and Garcia 2004, Blanchflower and Oswald 1999, Kaiser 2002) as well as the impression from univariate comparison of histograms. For instance, the country dummy variable for Denmark is positive and statistically highly significant (1\% level), cf. Table 1 .

\section{TABLE 1 ABOUT HERE}

Hence, based on the standard ordered probit model we would conclude that Danish workers have a higher level of job satisfaction than their Dutch counterparts (the Netherlands is used as reference country). Similarly, the indicator for Finland is statistically significant (5\% level) and positive, while the indicator variables for UK and France are negative and statistically significant, indicating a lower level of job satisfaction in these countries visà-vis the Netherlands.

Among the other covariates included in $X$, the parameter estimates for age, income and an indicator for female respondent are all positive and statistically significant. The parameter estimate for weekly work hours is negative as expected but not significant. Many studies have found that low educated, perhaps as a result of lower expectations, report a higher level of job satisfaction than individuals with relatively higher education (Clark 1999). We do not find any significant difference between education groups here - presumably because we condition the entire sample on people with relatively low education.

Generally, the results from the chopit model differ a lot from the results from the standard ordered probit model.

\footnotetext{
${ }^{5}$ The software is made available for free and can be downloaded from www.gllamm.org. Also see Skrondal and Rabe-Hesketh (2004).
} 
The Netherlands is now found to be the highest ranking country in terms of job satisfaction. Denmark ranks second but significantly lower than the Netherlands. Finland drops from its position as second highest ranked to be ranked in the fourth place, cf. Table 2 .

\section{TABLE 2 ABOUT HERE}

The parameter estimates for age, income and the female indicator change relatively little when the chopit model is estimated instead of the ordered probit. This indicates that correcting for cultural differences only plays a minor role for these covariates. On the other hand, the parameter estimate for weekly hours decreases substantially and becomes significant, indicating that there are cultural differences in the impact of working hours on job satisfaction.

As mentioned in section 2, the threshold parameters in the chopit model are allowed to depend on covariates. We have set $Z=X$ and hence we use the same covariates to determine the thresholds as we included as explanatory variables in the main part of the model. Although the covariates are insignificant for some of the thresholds, they generally appear to have some explanatory power and hence improve the overall fit of the model.

In the estimation of the first threshold parameter, $\tau_{1}$, the country dummy for, say, Denmark is found to be 0.189 and significant. This means that the Danes have a higher standard for what constitutes this particular level of job satisfaction (i.e. picturing a normal density distribution with 10 thresholds along the horizontal axis, the first threshold for Denmark is pushed to the right compared to the Netherlands). On the other hand, the country dummies for Denmark for thresholds 5-9 $\left(\tau_{5}-\tau_{9}\right)$ are negative and significant, which means that Danes have a lower standard for what constitutes these levels of job satisfaction than Dutch workers have. This explains why the ranking of the Netherlands and Denmark is reversed when the chopit model is estimated instead of the ordered probit model.

The log-likelihood value increases dramatically when we estimate the chopit model, and although the number of degrees of freedom lost is also very large, the chopit model clearly fits the data better than the ordered probit model. ${ }^{6}$

\footnotetext{
${ }^{6}$ The number of degrees of freedom is 205 (95 $\theta$-values and $10 \times 11=110$ extra parameters). The difference in likelihood values is 4,424 .
} 


\subsection{Sensitivity Analysis}

Are the results presented in the last section truly indicative of cultural differences in how questions about job satisfaction are perceived? Or could it be, alternatively, that the results spuriosly are driven by other factors?

One alternative explanation springs to mind. Perhaps the assumption about vignette equivalence is too strong. In our setting, where the value of attributes used in the vignettes is likely to depend on the institutional set-up in each country, it might well be that the cure is as bad as the disease, i.e. that the chopit model is invalid because the assumption of vignette equivalence doesn't hold. Although the seven countries are relatively homogeneous, "old" members of the EU, they may still be too different for the assumption of vignette equivalence to hold. In order to indirectly test whether this is the case, we split the sample according to the Inglehart values map, see Appendix C. ${ }^{7}$ Following the Inglehart map, we construct two groups of countries with similar cultures: Finland, Denmark and the Netherlands in one group (Protestant Europe) and Greece, Spain and France in another group (Catholic Europe). As UK, according to Inglehart's map, belongs to a third group, we omit the UK here and estimate both the ordered probit model and the chopit model for these two groups separately.

The results (available upon request) do not change the picture described above. The country dummy parameter estimates are left virtually unaffected by seperating the sample, and the conclusions remain unaltered.

\subsection{Discussion and Implications}

Cross-country differences in satisfaction, well-being and other subjective measures such as job satisfaction have been remarkably persistent across time. Inglehart and Klingemann (2000) refute the idea that cross-country differences should adhere to problems with translating questions and phrasing "satisfaction" adequately comparable across countries. Instead they argue that cross-cultural differences in well-being reflect societies' historical experiences and note that this may explain why country differences are so stable over time. They find that economic development and experience of communistic ruling of government are the two leading explanations for cross-country differences.

Our findings offer an alternative explanation for cross-country differences. We find that individuals in different cultures have varying standards for what constitutes particular levels of job satisfaction, and this has impor-

\footnotetext{
${ }^{7}$ http://www.worldvaluessurvey.org/statistics/index.html.
} 
tant bearings on their responses to subjective questions. When we control for the actual content of the job (through vignettes), the ranking between countries changes.

An important and immidiate consequence of our results is that one should be very careful in concluding that the Danish labor market model should necessarily serve as a role model for other countries. In fact, instead this study points to the Dutch model as the best in terms of job satisfaction.

Our results are also relevant for a wider public policy debate. Layard (2003) makes quite far-reaching public policy recommendations based on results from research on happiness. One of his major arguments starts from the result that, beyond a certain income level, the level of GDP per capita does not increase happiness. Hence, Layard (2003) argues that public policy should be oriented in such a way that excessive effort should be discouraged, most notably by the introduction of very high marginal taxes. However, our results imply that the comparison of average happiness across countries may be distorted by the fact that cultural values affect the way individuals answer questions on individual happiness, and this somewhat invalidates Layard's conclusion.

\section{Concluding Remarks}

In this paper, we apply conjoint analysis techniques in order to control for cultural differences in the way individuals from different countries perceive subjective questions about job satisfaction.

Using a standard ordered probit model, we obtain results much in line with previous studies, i.e. we find that employees in Denmark report the highest level of job satisfaction followed by Finnish workers. However, the chopit model results, where threshold parameters have been rescaled through vignette anchoring, alter the country ranking and place the Netherlands in the top and Denmark second while Finland drops to a fourth place, out of seven EU countries. Thus, our results implicate that cross-country comparisons of subjective answers of job satisfaction that are done without vignette anchoring may be grossly misleading. In the particular case of job satisfaction cross-country comparison applied here, we conclude that, if anything, the Dutch rather than the Danish labor market should serve as a role model to enhance job satisfaction in other countries. That we question simple cross-country comparison of job satisfaction corroborates studies of subjective assessment of health (Salomon et al. 2004) and political freedom (King et al. 2004). Another interesting implication of the mentioned research 
taken together with our contribution is that these results strongly suggest that the large literature on cross-country comparisons of well-being and satisfaction with life also needs to be revised by applying similar re-scaling techniques.

Future analyses could also include applying the chopit model to panel data. The analysis here is limited by the fact that we only observe a cross section of respondents, and hence we are unable to control for unobserved individual effects, which may capture individual personality traits. As noted in Diener and Lucas (1999), researchers in psychology have found that personality (inherit in the genes) accounts for up to 80 percent of subjective well-being, and this points to the importance of being able to control for individual-specific effects.

\section{References}

Ahn, N., and Garcia, J.R. (2004), Job Satisfaction in Europe. Documento de Trabajo 2004-16, Fedea, Spain.

Blanchflower D.G, and Oswald, A. (1999), Well-being, Insecurity, and the Decline of American Job Satisfaction. Mimeo, Univerity of Warwick.

Clark, A. (2001), What really matters in a job? Hedonic measurement using quit data", Labour Economics 8, 223-242.

Clark, A. (2005). What Makes a Good Job? Evidence from OECD Countries" in Bazen, S., Lucifora, C. and Salverda, W. (eds.) Job Quality and Employer Behaviour, Palgrave, 2005, 11-30.

Diener, E. and Lucas, R.E. (1999), Personality and subjective well-being, in Kahneman, D. Diener, E. and Schwarz, N. (eds.) Well-being. The foundations of Hedonic psychology, Russell Sage Foundation, New York.

Easterlin, R.A. (2001). Income and Happiness: Towards a Unified Theory. Economic Journal, 111, 465-484.

Eurobarometer (2002). Public Opinion in the European Union. European Commission, Spring 2002. Available at http://europa.eu.int/comm/public opinion/archives/eb/eb57/eb57_en.pdf 
European Commission (2001), Employment in Europe. Recent Trends and Prospects.

European Commission (2002), Employment in Europe. Recent Trends and Prospects.

European Commission (2003), Employment in Europe. Recent Trends and Prospects.

Frey, B., and Stutzer, A. (2002a), What Can Economists Learn from Happiness Research? Journal of Economic Literature, 40 (2), 402-435.

Frey, B., and Stutzer, A. (2002b), Happiness and economics: How the economy and institutions affect well-being. Princeton University Press, Princeton and Oxford.

Green, P.E. and Srinivasan, V. (1978). Conjoint analysis in consumer research: Issues and outlook. Journal of Consumer Research, 5, 103-123.

Groot, W. and van den Brink, H.M. (1999), Job satisfaction and preference drift. Economics Letters, 63, 363-367.

Inglehart, R., and Klingemann, H-D. (2000), Genes, culture, democracy and happiness, in (eds.) Diener, E., and Suh, E.M. Culture and subjective wellbeing, 165-184. MIT Press Cambridge.

Kaiser, L. C. (2002), Job Satisfaction: A Comparison of Standard, NonStandard, and Self-Employment Patterns across Europe with a Special Note to the Gender/Job Satisfaction Paradox. EPAG Working Paper 27. Colchester: University of Essex.

King, G. A., Murray, C. J. L., Salomon, J.A., and Tandon, A. (2004), Enhancing the Validity and Cross-Cultural Comparability of Measurement in Survey Research. American Political Science Review, 98 (1), 191-207.

Layard, R. (2003), Happiness: Has Social Science a Clue?. Lecture 1. What is happiness? Are we getting happier?. Available at http://cep.lse.ac.uk /events/lectures/layard/RL030303.pdf.

Patterson, M., Warr, P., and West, M. (2004), Organizational Climate and 
Company Productivity: The Role of Employee Affect and Employee Level. Journal of Occupational and Organizational Psychology, 77, 193-216.

Pfeffer, J. and Langton, N. (1993). The Effect of Wage Dispersion on Satisfaction, Productivity, and Collaboratively: Evidence from College and University Faculty. Administrative Science Quarterly, 38:382-407.

Rabe-Hesketh, N., and Skrondal, A. (2002), Estimating chopit models in gllamm - political efficacy example from King et al. (2002), available from http://www.gllamm.org/examples.html\#chopit

Salomon, J. A., Tandon, A., and Murray, C.J. (2004), Comparability of Self Related Health: Cross Sectional Multi-Country Survey Using Anchoring Vignettes. British Medical Journal, 328, 258-264.

Sen, A. (2002), Health: Perception Versus Observation. British Medical Journal, 324, 860-861.

Skrondal, A. and Rabe-Hesketh, S. (2004), Generalized Latent Variable Modeling. Multilevel, Longitudinal, and Structural Equation Models. Boca Raton Fl., Chapman and Hall/CRC.

Tandon, A., Murray, C.J.L., Salomon, J.A. and King, G. (2003), Statistical Models for Enhancing Cross-Population Comparability. In Murray, C.J.L. and Evans, D.B. (eds.) Health Systems Performance Assessment. Debates, Methods and Empiricism. World Health Organization, Geneva.

van Beek, K.W.H., Koopmans, C.C. and van Praag, B.M.S. (1997), Shopping at the labour market: A real tale of fiction. European Economic Review, 41, 295-317.

van Praag, B.M.S., and Ferrer-i-Carbonell, A. (2004), Happiness Quantified: A Satisfaction Calculus Approach. Oxford University Press, Oxford, UK.

Veenhoven (2000), Freedom and Happiness: A Comparative Study in Fortyfour Nations in the Early 1990s', in (eds.) Diener, E., and Suh, E.M. Culture and subjective well-being, 165-184. MIT Press Cambridge. 


\section{A Appendix: The Likelihood Function}

The joint likelihood can be split into a part for the self-assessment of job satisfaction and a part for vignettes.

The likelihood for the self-assessment component reads

$$
L_{s}(\beta, \gamma \mid j s) \propto \prod_{i=1}^{N} \prod_{k=1}^{10}\left[F\left(\tau_{i}^{k} \mid X_{i} \beta\right)-F\left(\tau_{i}^{k-1} \mid X_{i} \beta\right)\right]^{\mathbf{I}\left(j s_{i}=k\right)}
$$

The likelihood for the vignette component reads

$$
L_{v}(\theta, \gamma \mid v) \propto \prod_{l=1}^{L} \prod_{j=1}^{5} \prod_{k=1}^{10}\left[F\left(\tau_{l}^{k} \mid \theta_{j}, \sigma^{2}\right)-F\left(\tau_{l}^{k-1} \mid \theta_{j}, \sigma^{2}\right]^{\mathbf{I}\left(v_{l, j}=k\right)}\right.
$$

where the product is estimated over observations, vignettes and response categories, respectively.

The likelihoods needs to be estimated jointly as they share the same parameter vector $\gamma$. The joint likelihood therefore becomes

$$
L(\beta, \theta, \gamma \mid j s, v)=L_{s}(\beta, \gamma \mid j s) \times L_{v}(\theta, \gamma \mid v) .
$$




\section{B Appendix: Attribute Levels}

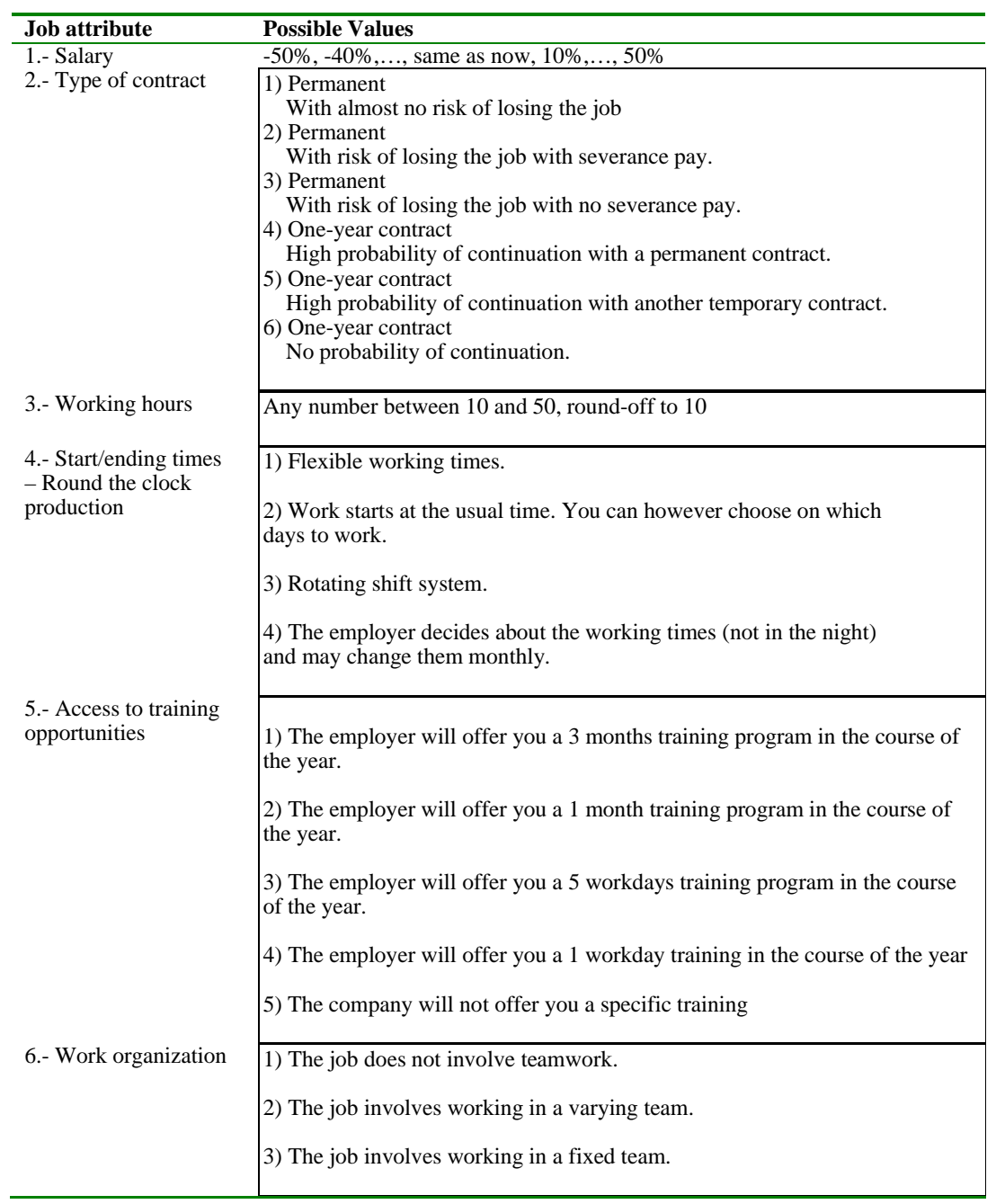




\begin{tabular}{|c|c|}
\hline $\begin{array}{l}\text { 7.- Control over own } \\
\text { work }\end{array}$ & $\begin{array}{l}\text { 1) The job has a completely fixed routine, which you cannot influence. } \\
\text { 2) Your job tasks are fixed, but you may decide on when and how things are } \\
\text { done. } \\
\text { 3) No one controls your work. }\end{array}$ \\
\hline 8.- Intensity & $\begin{array}{l}\text { 1) The job is very demanding, which means that you will have to work most } \\
\text { of the time at high speed. } \\
\text { 2) The job is fairly demanding, which means that sometimes you may have } \\
\text { to work at high speed. } \\
\text { 3) The job is not very demanding, which means that you will rarely have to } \\
\text { work at high speed. } \\
\text { 4) The job is very demanding, which means that most of the time you will } \\
\text { have to meet tight deadlines. } \\
\text { 5) The job is fairly demanding, which means that sometimes you may have } \\
\text { to meet tight deadlines. } \\
\text { 6) The job is not very demanding, which means that you will rarely have to } \\
\text { meet tight deadlines. }\end{array}$ \\
\hline $\begin{array}{l}\text { 9.- Time of retirement } \\
\& \text { labor disability }\end{array}$ & $\begin{array}{l}\text { 1) You will have to stop before retirement age } \\
\text { 2) You can retire at age X. } \\
\text { 3) This company has no early retirement plans. }\end{array}$ \\
\hline 10.- Akerlof theory & $\begin{array}{l}\text { 1) Same working conditions as in other firms } \\
\text { No loyalty from both sides } \\
\text { Shirking and low performance is possible. } \\
\text { 2) Same working conditions as in other firms } \\
\text { Loyalty from both sides } \\
\text { Shirking and low performance work is impossible }\end{array}$ \\
\hline
\end{tabular}




\section{Appendix: The Inglehart Value Map}

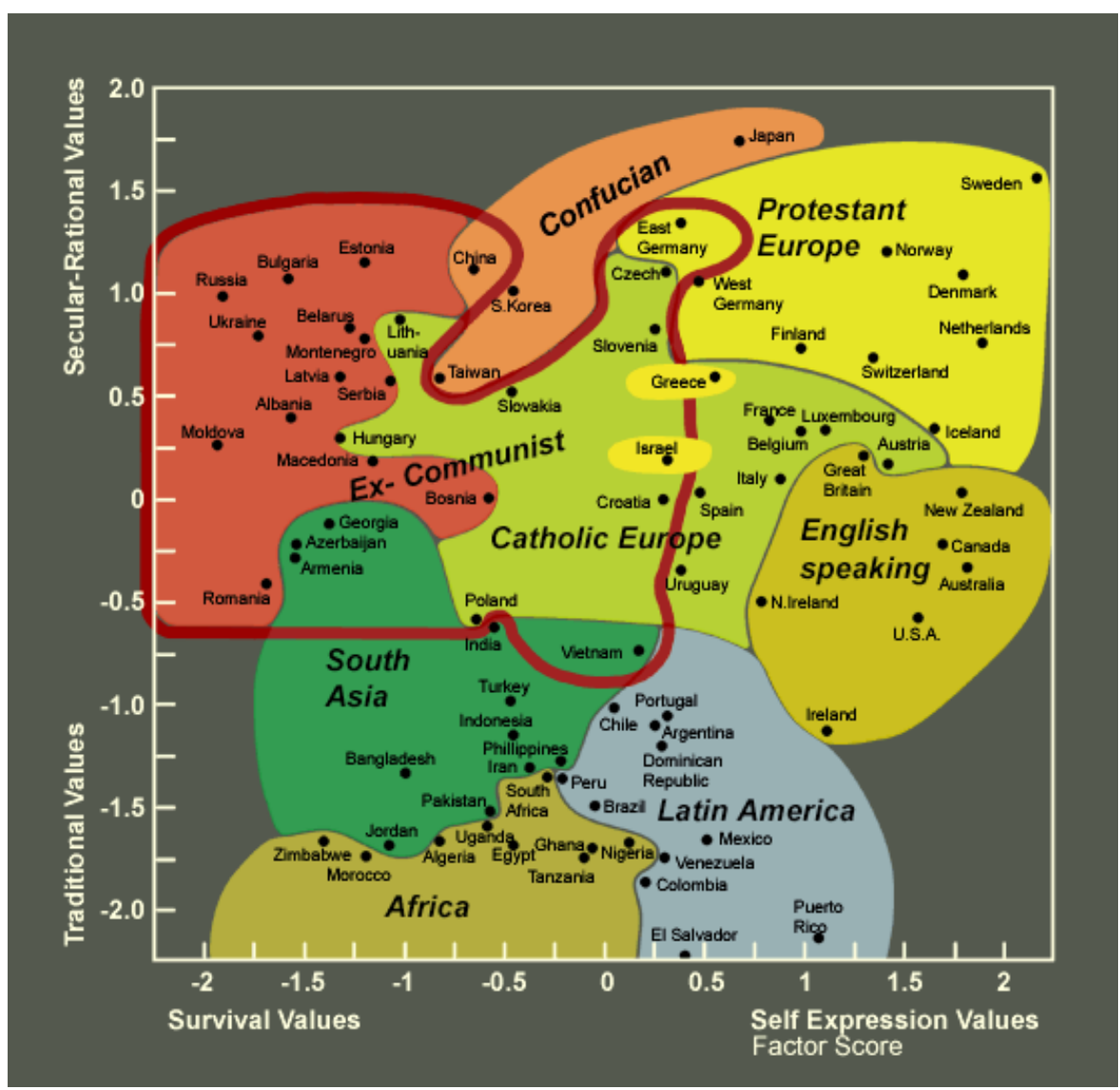

Source: http://www.worldvaluessurvey.org/statistics/index.html. 


\section{Appendix: Tables}

D.1 Table 1: Parameter estimates, Ordered probit and Chopit

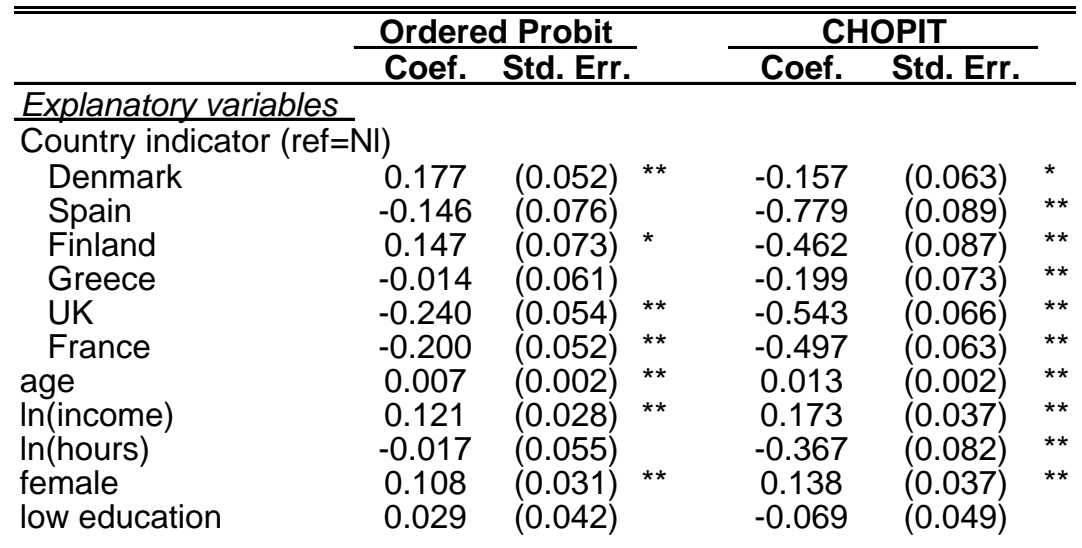

\begin{tabular}{l} 
Thresholds \\
\hline threshold 1 \\
Denmark \\
Spain \\
Finland \\
Greece \\
UK \\
France \\
age \\
In(income) \\
In(hours) \\
female \\
low education \\
constant
\end{tabular}

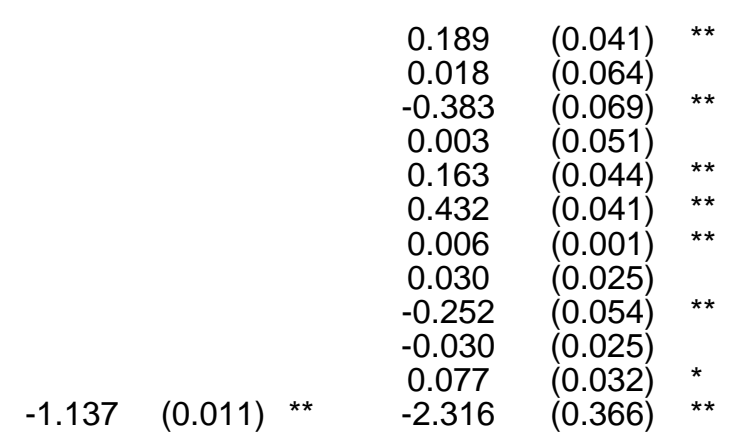

threshold 2

Denmark

Spain

Finland

Greece

UK

France

age

In(income)

In(hours)

female

low education

constant

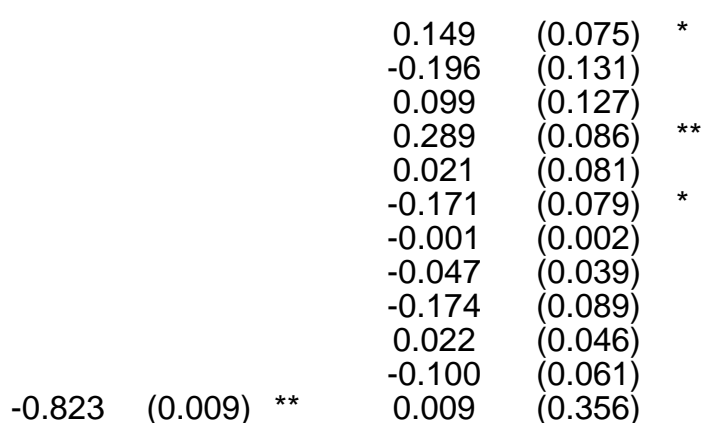




\begin{tabular}{|c|c|c|c|c|c|c|}
\hline Irestioia & & & & & & \\
\hline Denmark & & & & 0.093 & $(0.065)$ & \\
\hline Spain & & & & -0.027 & $(0.106)$ & \\
\hline Finland & & & & -0.182 & $(0.119)$ & \\
\hline Greece & & & & 0.285 & $(0.075)$ & ** \\
\hline UK & & & & 0.204 & $(0.068)$ & ** \\
\hline France & & & & -0.021 & $(0.069)$ & \\
\hline age & & & & 0.001 & $(0.002)$ & \\
\hline In(income) & & & & 0.053 & $(0.036)$ & \\
\hline In(hours) & & & & -0.142 & $(0.079)$ & \\
\hline female & & & & 0.011 & $(0.039)$ & \\
\hline low education & & & & -0.212 & $(0.055)$ & ** \\
\hline constant & -0.495 & $(0.008)$ & ** & -0.836 & $(0.313)$ & $* *$ \\
\hline threshold 4 & & & & & & \\
\hline Denmark & & & & 0.017 & $(0.059)$ & \\
\hline Spain & & & & -0.016 & $(0.091)$ & \\
\hline Finland & & & & 0.127 & $(0.089)$ & \\
\hline Greece & & & & 0.062 & $(0.069)$ & \\
\hline UK & & & & 0.073 & $(0.062)$ & \\
\hline France & & & & -0.176 & $(0.064)$ & ** \\
\hline age & & & & 0.000 & $(0.002)$ & \\
\hline In(income) & & & & 0.015 & (0.033) & \\
\hline In(hours) & & & & 0.184 & (0.077) & * \\
\hline female & & & & 0.047 & $(0.036)$ & \\
\hline low education & & & & -0.089 & $(0.051)$ & \\
\hline constant & -0.176 & $(0.008)$ & ** & -1.679 & $(0.304)$ & $* *$ \\
\hline threshold 5 & & & & & & \\
\hline Denmark & & & & -0.273 & $(0.063)$ & ** \\
\hline Spain & & & & -0.253 & $(0.097)$ & $* *$ \\
\hline Finland & & & & -0.140 & $(0.093)$ & \\
\hline Greece & & & & -0.079 & $(0.071)$ & \\
\hline UK & & & & -0.123 & $(0.064)$ & \\
\hline France & & & & -0.262 & $(0.063)$ & ** \\
\hline age & & & & 0.000 & $(0.002)$ & \\
\hline In(income) & & & & -0.011 & $(0.035)$ & \\
\hline In(hours) & & & & 0.096 & $(0.081)$ & \\
\hline female & & & & 0.014 & $(0.039)$ & \\
\hline low education & & & & 0.053 & $(0.051)$ & \\
\hline constant & 0.087 & $(0.008)$ & ** & -1.234 & $(0.322)$ & ** \\
\hline
\end{tabular}




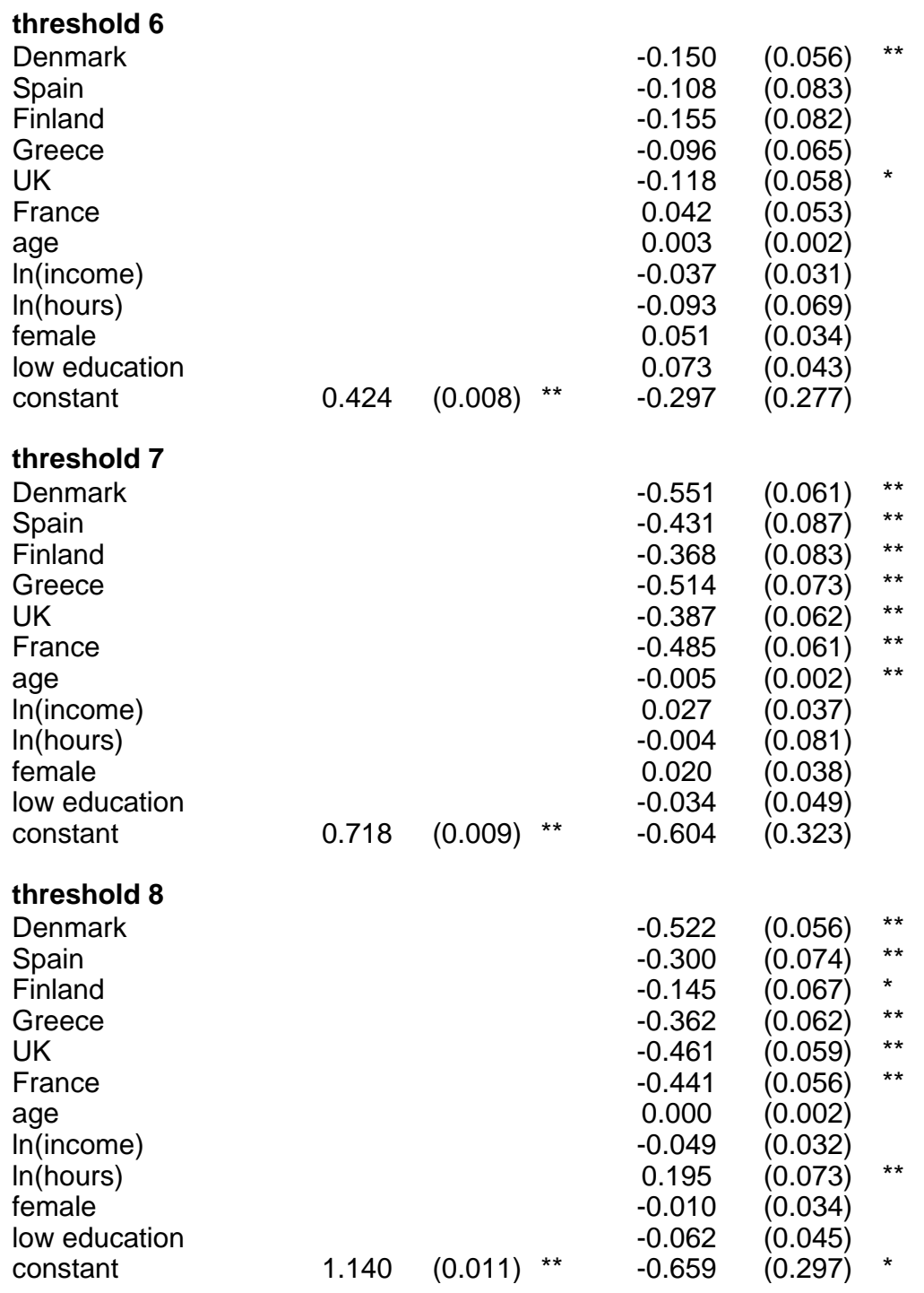




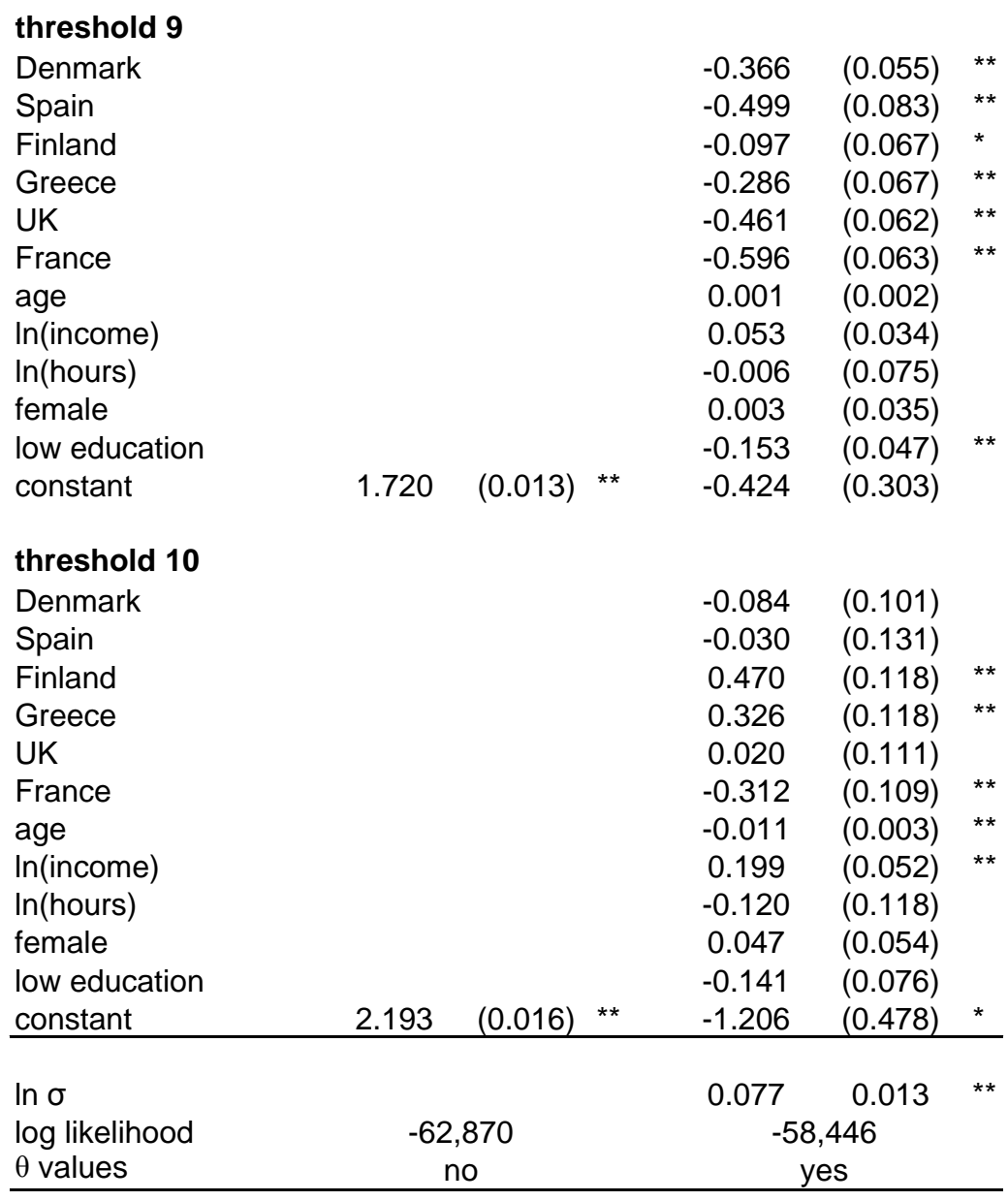

Note: Standard errors in parentheses. ${ }^{* *}=$ significant at the $1 \%$ level, ${ }^{*}=$ significant at the $5 \%$ level. 
D.2 Table 2: Country rankings

\begin{tabular}{cll} 
Rank & Ordered Probit & Chopit \\
\hline 1 & Denmark & Netherlands \\
2 & Finland & Denmark \\
3 & Netherlands & Greece \\
4 & Greece & Finland \\
5 & Spain & France \\
6 & France & UK \\
7 & UK & Spain \\
\hline \hline
\end{tabular}


Department of Economics:

Skriftserie/Working Paper:

2002:

WP 02-1 Peter Jensen, Michael Rosholm and Mette Verner: A Comparison of Different Estimators for Panel Data Sample Selection Models. ISSN 1397-4831.

WP 02-2 Erik Strøjer Madsen, Camilla Jensen and Jørgen Drud Hansen: Scale in Technology and Learning-by-doing in the Windmill Industry. ISSN 1397-4831.

WP 02-3 Peter Markussen, Gert Tinggaard Svendsen and Morten Vesterdal: The political economy of a tradable GHG permit market in the European Union. ISSN 13974831 .

WP 02-4 Anders Frederiksen og Jan V. Hansen: Skattereformer: Dynamiske effekter og fordelingskonsekvenser. ISSN 1397-4831.

WP 02-5 Anders Poulsen: On the Evolutionary Stability of Bargaining Inefficiency. ISSN $1397-4831$.

WP 02-6 Jan Bentzen and Valdemar Smith: What does California have in common with Finland, Norway and Sweden? ISSN 1397-4831.

WP 02-7 Odile Poulsen: Optimal Patent Policies: A Survey. ISSN 1397-4831.

WP 02-8 Jan Bentzen and Valdemar Smith: An empirical analysis of the interrelations among the export of red wine from France, Italy and Spain. ISSN 1397-4831.

WP 02-9 A. Goenka and O. Poulsen: Indeterminacy and Labor Augmenting Externalities. ISSN 1397-4831.

WP 02-10 Charlotte Christiansen and Helena Skyt Nielsen: The Educational Asset Market: A Finance Perspective on Human Capital Investment. ISSN 1397-4831.

WP 02-11 Gert Tinggaard Svendsen and Morten Vesterdal: CO2 trade and market power in the EU electricity sector. ISSN 1397-4831.

WP 02-12 Tibor Neugebauer, Anders Poulsen and Arthur Schram: Fairness and Reciprocity in the Hawk-Dove game. ISSN 1397-4831.

WP 02-13 Yoshifumi Ueda and Gert Tinggaard Svendsen: How to Solve the Tragedy of the Commons? Social Entrepreneurs and Global Public Goods. ISSN 1397-4831.

WP 02-14 Jan Bentzen and Valdemar Smith: An empirical analysis of the effect of labour market characteristics on marital dissolution rates. ISSN 1397-4831. 
WP 02-15 Christian Bjørnskov and Gert Tinggaard Svendsen: Why Does the Northern Light Shine So Brightly? Decentralisation, social capital and the economy. ISSN 13974831 .

WP 02-16 Gert Tinggaard Svendsen: Lobbyism and $\mathrm{CO}_{2}$ trade in the EU. ISSN 1397-4831.

WP 02-17 Søren Harck: Reallønsaspirationer, fejlkorrektion og reallønskurver. ISSN 13974831.

WP 02-18 Anders Poulsen and Odile Poulsen: Materialism, Reciprocity and Altruism in the Prisoner's Dilemma - An Evolutionary Analysis. ISSN 1397-4831.

WP 02-19 Helena Skyt Nielsen, Marianne Simonsen and Mette Verner: Does the Gap in Family-friendly Policies Drive the Family Gap? ISSN 1397-4831.

2003:

WP 03-1 Søren Harck: Er der nu en strukturelt bestemt langsigts-ledighed I SMEC?: Phillipskurven i SMEC 99 vis-à-vis SMEC 94. ISSN 1397-4831.

WP 03-2 Beatrice Schindler Rangvid: Evaluating Private School Quality in Denmark. ISSN 1397-4831.

WP 03-3 Tor Eriksson: Managerial Pay and Executive Turnover in the Czech and Slovak Republics. ISSN 1397-4831.

WP 03-4 Michael Svarer and Mette Verner: Do Children Stabilize Marriages? ISSN 13974831 .

WP 03-5 Christian Bjørnskov and Gert Tinggaard Svendsen: Measuring social capital - Is there a single underlying explanation? ISSN 1397-4831.

WP 03-6 Vibeke Jakobsen and Nina Smith: The educational attainment of the children of the Danish 'guest worker' immigrants. ISSN 1397-4831.

WP 03-7 Anders Poulsen: The Survival and Welfare Implications of Altruism When Preferences are Endogenous. ISSN 1397-4831.

WP 03-8 Helena Skyt Nielsen and Mette Verner: Why are Well-educated Women not Fulltimers? ISSN 1397-4831.

WP 03-9 Anders Poulsen: On Efficiency, Tie-Breaking Rules and Role Assignment Procedures in Evolutionary Bargaining. ISSN 1397-4831.

WP 03-10 Anders Poulsen and Gert Tinggaard Svendsen: Rise and Decline of Social Capital - Excess Co-operation in the One-Shot Prisoner's Dilemma Game. ISSN 13974831. 
WP 03-11 Nabanita Datta Gupta and Amaresh Dubey: Poverty and Fertility: An Instrumental Variables Analysis on Indian Micro Data. ISSN 1397-4831.

WP 03-12 Tor Eriksson: The Managerial Power Impact on Compensation - Some Further Evidence. ISSN 1397-4831.

WP 03-13 Christian Bjørnskov: Corruption and Social Capital. ISSN 1397-4831.

WP 03-14 Debashish Bhattacherjee: The Effects of Group Incentives in an Indian Firm - Evidence from Payroll Data. ISSN 1397-4831.

WP 03-15 Tor Eriksson och Peter Jensen: Tidsbegränsade anställninger - danska erfarenheter. ISSN 1397-4831.

WP 03-16 Tom Coupé, Valérie Smeets and Frédéric Warzynski: Incentives, Sorting and Productivity along the Career: Evidence from a Sample of Top Economists. ISSN 1397-4831.

WP 03-17 Jozef Koning, Patrick Van Cayseele and Frédéric Warzynski: The Effects of Privatization and Competitive Pressure on Firms' Price-Cost Margins: Micro Evidence from Emerging Economies. ISSN 1397-4831.

WP 03-18 Urs Steiner Brandt and Gert Tinggaard Svendsen: The coalition of industrialists and environmentalists in the climate change issue. ISSN 1397-4831.

WP 03-19 Jan Bentzen: An empirical analysis of gasoline price convergence for 20 OECD countries. ISSN 1397-4831.

WP 03-20 Jan Bentzen and Valdemar Smith: Regional income convergence in the Scandinavian countries. ISSN 1397-4831.

WP 03-21 Gert Tinggaard Svendsen: Social Capital, Corruption and Economic Growth: Eastern and Western Europe. ISSN 1397-4831.

WP 03-22 Jan Bentzen and Valdemar Smith: A Comparative Study of Wine Auction Prices: Mouton Rothschild Premier Cru Classé. ISSN 1397-4831.

WP 03-23 Peter Guldager: Folkepensionisternes incitamenter til at arbejde. ISSN 1397-4831.

WP 03-24 Valérie Smeets and Frédéric Warzynski: Job Creation, Job Destruction and Voting Behavior in Poland. ISSN 1397-4831.

WP 03-25 Tom Coupé, Valérie Smeets and Frédéric Warzynski: Incentives in Economic Departments: Testing Tournaments? ISSN 1397-4831.

WP 03-26 Erik Strøjer Madsen, Valdemar Smith and Mogens Dilling-Hansen: Industrial clusters, firm location and productivity - Some empirical evidence for Danish firms. ISSN 1397-4831. 
WP 03-27 Aycan Çelikaksoy, Helena Skyt Nielsen and Mette Verner: Marriage Migration: Just another case of positive assortative matching? ISSN 1397-4831.

2004:

WP 04-1 Elina Pylkkänen and Nina Smith: Career Interruptions due to Parental Leave - A Comparative Study of Denmark and Sweden. ISSN 1397-4831.

WP 04-2 Urs Steiner Brandt and Gert Tinggaard Svendsen: Switch Point and First-Mover Advantage: The Case of the Wind Turbine Industry. ISSN 1397-4831.

WP 04-3 Tor Eriksson and Jaime Ortega: The Adoption of Job Rotation: Testing the Theories. ISSN 1397-4831.

WP 04-4 Valérie Smeets: Are There Fast Tracks in Economic Departments? Evidence from a Sample of Top Economists. ISSN 1397-4831.

WP 04-5 Karsten Bjerring Olsen, Rikke Ibsen and Niels Westergaard-Nielsen: Does Outsourcing Create Unemployment? The Case of the Danish Textile and Clothing Industry. ISSN 1397-4831.

WP 04-6 Tor Eriksson and Johan Moritz Kuhn: Firm Spin-offs in Denmark 1981-2000 Patterns of Entry and Exit. ISSN 1397-4831.

WP 04-7 Mona Larsen and Nabanita Datta Gupta: The Impact of Health on Individual Retirement Plans: a Panel Analysis comparing Self-reported versus Diagnostic Measures. ISSN 1397-4831.

WP 04-8 Christian Bjørnskov: Inequality, Tolerance, and Growth. ISSN 1397-4831.

WP 04-9 Christian Bjørnskov: Legal Quality, Inequality, and Tolerance. ISSN 1397-4831.

WP 04-10 Karsten Bjerring Olsen: Economic Cooperation and Social Identity: Towards a Model of Economic Cross-Cultural Integration. ISSN 1397-4831.

WP 04-11 Iben Bolvig: Within- and between-firm mobility in the low-wage labour market. ISSN 1397-4831.

WP 04-12 Odile Poulsen and Gert Tinggaard Svendsen: Social Capital and Market Centralisation: A Two-Sector Model. ISSN 1397-4831.

WP 04-13 Aditya Goenka and Odile Poulsen: Factor Intensity Reversal and Ergodic Chaos. ISSN 1397-4831.

WP 04-14 Jan Bentzen and Valdemar Smith: Short-run and long-run relationships in the consumption of alcohol in the Scandinavian countries.

ISBN 87-7882-010-3 (print); ISBN 87-7882-011-1 (online). 
WP 04-15 Jan Bentzen, Erik Strøjer Madsen, Valdemar Smith and Mogens Dilling-Hansen: Persistence in Corporate Performance? Empirical Evidence from Panel Unit Root Tests.

ISBN 87-7882-012-X (print); ISBN 87-7882-013-8 (online).

WP 04-16 Anders U. Poulsen and Jonathan H.W. Tan: Can Information Backfire? Experimental Evidence from the Ultimatum Game.

ISBN 87-7882-014-6 (print); ISBN 87-7882-015-4 (online).

WP 04-17 Werner Roeger and Frédéric Warzynski: A Joint Estimation of Price-Cost Margins and Sunk Capital: Theory and Evidence from the European Electricity Industry. ISBN 87-7882-016-2 (print); ISBN 87-7882-017-0 (online).

WP 04-18 Nabanita Datta Gupta and Tor Eriksson: New workplace practices and the gender wage gap.

ISBN 87-7882-018-9 (print); ISBN 87-7882-019-7 (online).

WP 04-19 Tor Eriksson and Axel Werwatz: The Prevalence of Internal Labour Markets New Evidence from Panel Data.

ISBN 87-7882-020-0 (print); ISBN 87-7882-021-9 (online).

WP 04-20 Anna Piil Damm and Michael Rosholm: Employment Effects of Dispersal Policies on Refugee Immigrants: Empirical Evidence.

ISBN 87-7882-022-7 (print); ISBN 87-7882-023-5 (online).

2005:

WP 05-1 Anna Piil Damm and Michael Rosholm: Employment Effects of Dispersal Policies on Refugee Immigrants: Theory.

ISBN 87-7882-024-3 (print); ISBN 87-7882-025-1 (online).

WP 05-2 Anna Piil Damm: Immigrants' Location Preferences: Exploiting a Natural Experiment.

ISBN 87-7882-036-7 (print); ISBN 87-7882-037-5 (online).

WP 05-3 Anna Piil Damm: The Danish Dispersal Policy on Refugee Immigrants 1986-1998: A Natural Experiment?

ISBN 87-7882-038-3 (print); ISBN 87-7882-039-1 (online).

WP 05-4 Rikke Ibsen and Niels Westergaard-Nielsen: Job Creation and Destruction over the Business Cycles and the Impact on Individual Job Flows in Denmark 1980-2001. ISBN 87-7882-040-5 (print); ISBN 87-7882-041-3 (online).

WP 05-5 Anna Maria Kossowska, Nina Smith, Valdemar Smith and Mette Verner: Til gavn for bundlinjen - Forbedrer kvinder i topledelse og bestyrelse danske virksomheders bundlinje?

ISBN 87-7882-042-1 (print); ISBN 87-7882-043-X (online). 
WP 05-6 Odile Poulsen and Gert Tinggaard Svendsen: The Long and Winding Road: Social Capital and Commuting.

ISBN 87-7882-044-8 (print); ISBN 87-7882-045-6 (online).

WP 05-7 Odile Poulsen and Gert Tinggaard Svendsen: Love Thy Neighbor: Bonding versus Bridging Trust.

ISBN 87-7882-062-6 (print); ISBN 87-7882-063-4 (online).

WP 05-8 Christian Bjørnskov: Political Ideology and Economic Freedom.

ISBN 87-7882-064-2 (print); ISBN 87-7882-065-0 (online).

WP 05-9 Sebastian Buhai and Coen Teulings: Tenure Profiles and Efficient Separation in a Stochastic Productivity Model.

ISBN 87-7882-066-9 (print); ISBN 87-7882-067-7 (online).

WP 05-10 Christian Grund and Niels Westergård-Nielsen: Age Structure of the Workforce and Firm Performance.

ISBN 87-7882-068-5 (print); ISBN 87-7882-069-3 (online).

WP 05-11 Søren Harck: AD-AS på dansk.

ISBN 87-7882-070-7 (print); ISBN 87-7882-071-5 (online).

WP 05-12 Søren Harck: Hviler Dansk Økonomi på en Cobb-Douglas teknologi?

ISBN 87-7882-092-8 (print); ISBN 87-7882-093-6 (online).

2006:

WP 06-1 Nicolai Kristensen and Edvard Johansson: New Evidence on Cross-Country Differences in Job Satisfaction Using Anchoring Vignettes.

ISBN 87-7882-094-4 (print); ISBN 87-7882-095-2 (online). 